\title{
The role(s) of accounting and performance measurement systems in contemporary public administration
}

Guest editors: Ileana Steccolini, Essex Business School, UK Iris Saliterer, Albert-Ludwigs Universität Freiburg; GER; James Guthrie, Macquarie University, AUS

\section{Public Administration}

\section{ABSTRACT}

The spate of public sector reforms which have taken place in the last decades has triggered the development of a new body of research around public sector accounting and performance measurement both in public administration as well as in the (public sector) accounting literature. However, studies in accounting and public administration have at times ignored each other, proceeding in parallel.

This symposium encourages the adoption of interdisciplinary perspectives in exploring the myriad roles played by accounting and performance management systems in contemporary public administration. Emphasizing that accounting and performance measurement systems are socially, politically, culturally constructed and, in turn, are implicated in the creation of organizations, society, and political values, this symposium aims at extending the dialogue between accounting and public administration scholars in exploring how accounting, accountability and performance measurement considerations are connected to policymaking, public services and more generally the building and maintenance of modern states and democracies.

\section{Introduction}

Accounting and measurement systems in public administration have often been seen as elements of an overall and loosely defined "administrative capacity", supporting managers and 
policymakers through the provision of information and, more generally, reinforcing democratic processes through the possibilities of transparency and accountability. As such, the instrumental, purposive nature of accounting has often been emphasized, pointing to it as being a means to an end, such as better decision making, or ensuring accountability on the use of public resources. At the basis of this functional conception is the idea that accounting is a neutral, technical "tool", designed and used by "experts", and seen with a mixture of fear and acritical trust (or lack therein) by non-experts. This layperson's view of accounting in the public realm is contrasted by the central role played by accounting and performance measurement systems in public sector reforms (e.g. Guthrie et al. 1999; Hood 1995; Humphrey et al. 2005). Accounting, and here in particular performance measurement systems, have been described as being the "technical lifeblood" of New Public Management (NPM) movements_(Olson et al., 1998), translating the principles of economic rationality and result orientation into operational practices, tools and processes in the public sector (Hood 1991; Miller and Rose 2008; Miller and Power 2013). NPM has therefore been identified as a trigger for the development of a new body of research around public sector accounting and performance measurement both in public administration as well as in (public sector) accounting literature (see Steccolini 2019; Lapsley 2008; Kurunmäki 2008). Surprisingly, however, studies in accounting and public administration, while looking at similar phenomena, have at times ignored each other, proceeding in parallel.

As public sector reforms progressed in the last decades, an essential body of research in both disciplines has looked at their antecedents, processes and consequences. Increasingly, scholars have shown how accounting, performance measurement, and quantification in the public sector, far from being neutral "means to ends", have produced significant consequences, affecting people, organizations, policies, culture, and society and deploying both expected and unexpected effects. Along these lines, a number of empirical studies have revealed that the 
adoption and use of performance measurement systems in the public sector produced not only unexpected but even undesired effects; the latter possibly resulting from poor implementation, lack of use, decoupling between actual and declared practices, the resistance to the adopted accounting and performance measurement systems (for example, Ter Bogt and Van Helden 2000; Brignall and Modell 2000; De Lancer Julnes and Holzer,2001; Broadbent and Laughlin 1998; Liguori and Steccolini 2014), or, more fundamentally, from their inbuilt programmatic ambitions (Miller 2001). Also, this literature has broadly acknowledged that their positive effects on public sector performance cannot be taken for granted (for example, Bevan and Hood 2006; Modell 2009; Arnaboldi et al. 2015; Hvidman and Andersen 2013; Walker et al. 2011; Speklé and Verbeeten 2014).

If accounting and performance measurement systems are to improve, and not hinder, public administration decision making and accountability, a better understanding is needed on how they are shaped by, and, in turn, also shape organizational, psychological, economic, social and political values and realities.

While there have been attempts to address this challenge in both disciplines, paradigmatic and disciplinary silos, not least arising from the application of different perspectives and methods (see, e.g. Van Helden et al. 2008; Steccolini 2019), may have prevented a comprehensive, fullrounded interdisciplinary understanding of such phenomena.

This symposium called for contributions from public administration and accounting scholars alike, encouraging them to take an interdisciplinary stance and shed fresh lights on the role of public sector accounting and performance measurement systems in contemporary public administration research, emphasizing that accounting and performance measurement systems are socially, politically, and culturally constructed and, in turn, implicated in the construction of organizational, psychological, economic, social and political values. This editorial briefly describes recent developments in accounting and performance measurement literature, setting 
the context for discussing the contributions offered by the paper in this symposium, and concludes with some final reflections and ways forward.

\section{Accounting and performance measurement systems in public administration: intersecting or parallel research endeavours?}

At the end of the Eighties, Lapsley's (1988) review paper documented a virtual absence of accounting research focused on public sector and services. Yet, this paper probably decreed the beginning of a new attention, in accounting scholarship, towards public sector accounting, as witnessed by relevant reviews of public sector accounting research developed, among others, by Broadbent and Guthrie (1992, 2008), Goddard (2010), Modell (2009, 2013), Van Helden et al. (2008), Jacobs (2012, 2013), and Anessi-Pessina et al. (2016). As pointed out by Steccolini (2019), such reviews show how increasingly public sector accounting became the technical language necessary to support the cultural shift to a quantifiable, managerial, marketized public sector, responding to the need of translating NPM ideologies and neo-liberalism into concrete apparatuses and systems (Humphrey et al. 1993; Lapsley 1999, 2009; Humphrey and Miller 2012; Liguori and Steccolini 2014). This gave rise to a body of research exploring the quantification and accountingization phenomena and the emergence of an "audit society" (for example, Power 1997, 2000, 2003; Miller 1994, 2001; Kurunmaki et al. 2003; Lapsley 2009). This group of scholars propose that NPM inspired accounting and performance measurement systems values may even be at odds with the traditional political and professional logics underlying public services (see for example, Broadbent and Laughlin 1998; Broadbent et al. 2001; De Lancer Julnes and Steccolini 2015), crowding-out motivation and service-related activities (for example, Olson et al. 2001; Hood 2002), or even leading to a stronger lenience toward a compliance mentality (for example, Power 2003; Hood and Peters 2004; Lapsley 2009). In all, this literature, relying on a variety of theoretical frames, including, among others, 
institutionalist theories, governmentality, Bourdieusian and Latour/Callon inspired approaches provides a vivid and rich picture on NPM reforms, their processes and consequences, often pointing to the emergence of unwanted and unexpected outcomes.

In parallel with such developments in accounting scholarship, in the public administration literature, performance measurement, seen as NPM's 'major feature' (Hughes 2007, p. 60), gave rise to a number of studies exploring how the design, adoption and use of accounting and performance measurement systems are altered in the expectation that this would translate into better outcomes (for example, De Lancer Julnes and Holzer 2001; Melkers and Willoughby 2005; Van De Walle and Van Dooren 2008; Taylor 2009, 2011; Moynihan et al. 2012a, 2012b; Kroll 2014). Within this stream of research, an important field of investigation has been (and still is) the identification of contextual, organizational and individual factors which explain "purposeful" performance information use by managers and politicians, often through quantitative analyses (e.g. Melkers and Willoughby 2005; Ammons and Rivenbark 2008; Taylor 2009, 2011; Moynihan and Pandey 2010; Moynihan et al. 2012b; Kroll 2014, 2015), ie, the use of performance information aimed at supporting better decision making.

This focus on purposeful use is in line with an instrumental, functionalist view of performance measurement systems (Hatry 2007). Although at times acknowledged, the symbolic, legitimizing, social and political roles and uses of performance measurement have largely been downplayed in public administration empirical studies (Korac et al. 2019, see Moynihan et al. 2012a for an exception). Conversely, interpretive accounting literature has recognized these features of accounting for a long time (see, e.g. Boland and Pondy 1983; Burchell et al. 1980: Ansari and Euske 1987; Markus and Pfeffer 1983) and in recent times there has been a resurgence of attention in the roles played by accounting in economy, society and organizations (Miller and Power 2013), as well as more specifically in the public sector (see, Giacomini et. al. 2016; Korac et al. 2019; Nitzl et. al. 2018; Saliterer et. al. 2019). Such studies have pointed 
to a variety of roles of accounting and to the need for contextualizing them, for example looking at organizational culture, policy phases or other conditions influencing uses and their consequences on behaviours and performance.

More recently, performance measurement, and especially the use of performance information, has also attracted significant attention in behavioural public administration research, where scholars have embraced insights from behavioural science (and psychology in particular) in exploring the effects of performance information on individuals' perceptions, use and decisionmaking behaviours. Mainly applying experimental designs, these studies provide new insights into how individuals process performance data (see Moynihan 2018; Barrows et al. 2016: James and Mosley 2014; Olsen 2015, 2017; Nielsen and Baekgaard 2015; Belardinelli et al. 2018). While there has been a strong focus on exploring a range of cognitive biases (e.g., negativity bias, anchoring effects) related to the presentation/processing of performance information (e.g., Moynihan 2018; Belardinelli et al. 2018; Battaglio et al. 2019), scholars have also started to look at the micro-foundations of the role of broader organizational and institutional factors, such as institutional pressures (Bellé et. al. 2018; Nielsen and Moynihan 2017), in influencing the use of performance information in decision making. In this regard, experimental designs may fall short in capturing organizational or environmental constructs (see, also Moynihan 2018) and may need to be complemented by or combined with other methods (Belle et al. 2018) and perspectives. In particular, qualitative research, eventually bridging and integrating perspectives from different disciplines, which devotes its attention to exploring the social and organizational antecedents and effects of accounting and performance measurement systems, may offer a reference point for developing studies linking contemporary social and organizational practices in public administration with accounting-related individual choices and behaviours. In this regard accounting literature has explored the effects of performance management system (e.g., Ter Bogt and Van Helden 2000; Liguori and Steccolini 
2014; Modell 2009; Lapsley 1999, 2009) with a more interpretive and qualitative stance, therefore allowing an in-depth reflection not only on the possible relationship between performance measurement systems, their antecedents and potential effects, but also on the myriad roles played by such systems in the public realm (see, Steccolini 2019). Interdisciplinary accounting studies focus on these aspects and can provide a more nuanced view on such roles, which may be of particular interest and relevance in a context where multiple logics and rationalities (Humphrey and Miller 2012) are at play, hybrid arrangements become the norm for public service provision, and the logics underlying public services become increasingly blurred and ever-changing (e.g., Hyndman et al. 2014; Liguori et al. 2017; Parker 2012; Wiesel and Modell 2014).

This short review recalls to our attention that accounting and performance measurement systems are at the intersection between various disciplines, sectors, professions, interests and powers. A single discipline may, therefore, be ill-suited to appreciate the broader possibilities of accounting and performance measurement systems antecedents and effects. While intersection and cross-pollination of research across disciplines have happened in cases (see, also Steccolini 2019), more knowledge is required on the individual, organizational and social consequences and implications of the processes of quantification, accountingization and measurement of performance, especially in the face of new challenges emerging for public services, including, among others, wicked problems (Ferlie et al. 2011), austerity and crises (Bracci et al., 2015), hybridization (Miller et al. 2008), the opening of paradigmatic gaps (Coen and Robert 2012) and the lack of engagement between practitioners and academics (Ferry et. al. 2019).

\section{The articles in the symposium}


The final six papers accepted for this symposium offer an exciting overview of the variety of approaches, theories and perspectives on the roles of accounting and performance measurement in public administration. They all point to the diversity of uses of performance measures, showing that multi-faceted accounting and quantification processes can be found in the public sector.

Along these lines, both George et al. (2019) and Micheli and Pavlov (2017) explore and identify the possible drivers of performance information use(s), with the former mainly focusing on how institutional forces influence politicians' behaviours, and the latter exploring internal organizational dynamics, and how, and, importantly, why different actors will favour different uses.

George et al. (2019) explored institutional pressures and possible negativity bias in exploring the drivers of performance information use by politicians in Flemish local governments. The role of institutional forces has been considered in empirical research on performance measurement systems (see, Korac et al. 2019; Brignall and Modell 2000; Van Helden et al. 2008; Modell 2009; Johansson and Siverbo 2009). However, applying an experimental design, the authors not only set foot in the newly created paths by scholars focusing on behavioural public administration but at the same time introduce a contextual perspective (James et. al. 2017), by modifying scenarios to mirror coercive, mimetic and normative pressures. While coercive pressures (comparisons with a centrally set performance standard) appears to lead to a higher intended performance information use, normative pressures (comparisons with performance standards recommended by a professional organization), encourage respondents to share contact details in order to learn more about the performance indicator. Mimetic pressures (comparisons with other local governments) however seem to have no impact. Following insights from the field of psychology, the authors also analyze how positive or negative deviations from an externally set performance standard act as possible antecedents of 
performance information use. Surprisingly, not only negative but also positive deviations from the performance standard lead to higher use intentions.

Also focusing on the use of performance information, Micheli and Pavlov (2017) address the tension between two different uses of performance information, 'passive', to ensure compliance, and 'purposeful', to improve public services. In their case study of two English public sector organizations, they explore both diversity of uses of performance information (passive, purposeful), and how such uses intertwine and combine. This article, therefore, adds to the (still) low number of studies that focus on exploring the drivers of and relationships between different performance information use types (Giacomini et. al. 2016, Korac et. al. 2019; Saliterer et. al. 2019; Nitzl et. al. 2018). In contrast to the predominantly quantitative studies in public administration that have explored performance information use, the authors apply a qualitative approach for investigating the dynamics between passive and purposeful use. In doing so, they demonstrate how managers with different seniority (would) resort to different forms of uses of performance measures. While senior managers appear to combine passive and purposeful uses, middle managers and frontline staff seem to rely on a more passive use (i.e. utilizing it mainly for reporting and compliance purposes). From the authors' perspective, the latter is particularly problematic as organizations may thereby miss out in using their frontline staff's insight to improve service delivery. The merit of this study lies in its qualitative design that allows drawing a more nuanced picture of the underlying reasons for combined use as well as for the observed lack of purposeful use that appears to stem from diverging sense-making by the actors, and less so from diverging interests.

The next papers in this special issue adopt case study approaches to explore the role of different drivers of the institutionalization of performance measurement systems, the dynamics of such systems, as well as their effects and consequences. Along these lines, the articles by Carter et al. (2019) and van Erp et al. (2018) both look at change processes. The former explores the 
roles of accounting alongside organizational leadership and strategy in influencing change. The latter, being set in a networked context, observes how external regulatory strategies and multiple accountability arrangements affect the implementation of performance management. Ahmad et al. (2018), in contrast, explore the effects of a performance management regime in a hybrid model of public service delivery by analysing its potential of influencing the behaviour of service delivery organizations in order to achieve desirable or predetermined outcomes. While the first-mentioned study mainly focuses on the organizational level, the latter two point to the relevance of accounting in mediating the relationship among different organizations, be they separate institutions, or networked ones.

A more detailed view reveals how these three articles contribute to this symposium's leading questions regarding the role of accounting and performance measurement in public administration. In their case study of the BBC, Carter et al. (2019) explored how calculative practices intertwined with other forces of change in the context of strategic shifts, emphasizing the relationships between accounting, strategy and leadership and pointing to the centrality of accounting systems in bringing about organizational change. Their research is a demonstration of how leadership and accounting combined in several ways, pointing to the territorializing, subjectivising, mediating and adjudicating roles of accounting. (Miller and Power 2013). The authors not only address the interplay of these forces but also consider the broader political context and the role of senior executive agency and leadership in this change process. This draws attention to the ways in which economizing, accounting and organizing are linked and therefore highlighting that much can be gained from a generative dialogue between the two disciplines.

Van Erp et al. (2018) explore the role of responsive regulations (i.e. non-coercive, educative interventions; informal, professional social control; reputational pressure; and sanctions as last resort) in ensuring the compliance with a performance measurement regime (i.e. DRG) which 
is used for resource allocation in a setting that is characterized by multiple networked actors and logics. Using a mixed-method approach, combining almost 60 interviews with network actors and a survey of over 600 medical specialists, the results show that a non-coercive, persuasive and mainly dialogue-oriented regulatory strategy to engage with the emerging accountability structures in the network (i.e. new actors and mechanisms) stimulated attitudinal and behavioural changes. The study offers rich findings and implications for implementing performance measurement systems in networked settings which increasingly characterize contemporary public service delivery. While, previously, the importance of regulators in a network context has often been portrayed as dwindling, this study shows how they can act as change agents/facilitators contributing to institutionalized, rather than cosmetic, forms of compliance with performance regulations. This study also gives insights into the interplay of (emerging) multiple accountability forms (e.g. professional, administrative, social accountability), how they impact the relationships between and the roles of different network actors over time, and how the networked character of performance regulation may assist in bridging gaps between administrative and clinical logics.

In a similar vein, but focusing on the transport sector, Ahmad et al. (2018) examined how UK road PFI contracts are managed during their operational stages (i.e. PPPs in action, see, Andon 2012). The authors analyse the potential of a performance management regime in influencing the behaviour of actors in a hybrid model of public service delivery to achieve desirable or predetermined outcomes. In this context, management control systems have to fulfil various roles of assessment, monitoring, managing, reporting, accountability and policy direction (see, Andon 2012), to reconcile the multiple, and sometimes also conflicting interests of different players. The case study by Ahmad et al. (2018) not only highlights the shortcomings of operationalizing and incentivising the achievement of contract objectives but also uncovers the significant challenge of balancing the tensions between different functions of control systems 
(i.e., monitoring and penalizing versus incentivizing functions). The authors show that pragmatism and trust-based practices play an enabling role in mediating these tensions, and also contribute to further sustaining inter-party relationships by providing opportunities for adapting the monitoring and incentive mechanisms. By using new conceptual lenses for exploring the effects, and the adaptation, of management control systems in hybrid settings, this paper provides interesting points of reference for further connecting accounting and public administration research.

Finally, Triatanfillou (2019) study of Danish Supreme Audit Institution positions to a longlasting dilemma in the accountability literature (i.e., the inherent tension between independence and relevance). While similar to other Supreme Audit Institutions and Courts of Audit, the Danish Supreme Audit Institution is required to maintain a high level of independence, it is also expected to produce audits which are relevant for governments. The paper argues that the simultaneous pursuit of independence and relevance is challenging and amounts to a zero-sum or a modest plus-sum game. The Danish Supreme Audit Institution, while focusing on both, has generally prioritized independence over relevance, as this priority seems to be an effective strategy to maintain legitimacy in the context of minority governments.

Finally, the paper in this Public Administration symposium offer a multi-faceted portrait of how accounting and calculation devices are connected to contemporary changes in public administration, and of the inherent tensions and challenges that their adoption, implementation and use may cause in the public arena. Interestingly, these studies illuminate and exemplify the diversity of epistemological, methodological and theoretical approaches taken by scholars in this critical area of research, as well as the multiplicity of contexts where it takes place.

These contributions highlight how public sector accounting and performance measurement systems can be conceptualized from different perspectives. Accounting can be interpreted in the narrow sense of information and support for decision making (i.e. as an "answer machine", 
Burchell et al., 1980), or have richer meanings. It can be seen as a driver for change or being the subject of change itself. Moreover, it can become a "learning" or "ammunition machine" (Burchell et al. 1980; Giacomini et al. 2016), giving rise to purposeful, political, passive, or even perverse uses (Moynihan 2009). Finally, as pointed out by Miller and Power (2013), accounting can play significantly different roles in society and organizations, ranging from territorializing, to adjudicating, subjectivizing, and mediating. This variety of roles and uses may strengthen each other, but also bear the risk of trade-offs and tensions. The latter have been pointed out in the accounting literature, but acquire specific meanings in the public sector. In the public sector, such tensions end up embodying or exacerbating the pertinent conflicts between professional, managerial and political logics, or between the different pressures converging on public services and policies.

As such, the long-debated tensions between the use of accounting as a tool for informing users, or controlling expenditure and the necessity for it to be a source of independence, and the basis for accountability, but also relevant for decision makers, and thus the basis for decision making, ignite contradictions and paradoxes, which the studies of this symposium contribute to illuminating, if not solve.

\section{Final reflection and possible way forwards}

The diversity of the approaches and themes that emerged from this symposium is a testimony to the richness and potential of this area of research, and as such, we hope it will encourage further inter- and multi-disciplinary endeavours in this area. In this concluding section, we develop a few final reflections.

First, this symposium reveals that a plurality of theoretical perspectives and research methods is needed to appreciate the complexity of contemporary issues in performance management and accounting in public administration. Similarly, the diversity of methods adopted is a 
richness which we should encourage. While qualitative studies focusing on performance measurement still face resistance and suspicion in public administration scholarship (Ospina et al. 2018; Nowell and Albrecht 2018), qualitative approaches in accounting have a strong tradition, with important journals in the accounting field (eg. Accounting, Auditing and Accountability Journal, Accounting, Organizations and Society, Critical Perspectives on Accounting, Financial Accountability and Management or the Journal of Qualitative Research in Accounting and Management) publishing in this area and encouraging interdisciplinarity and openness to methodological experimentation (Parker and Northcott 2016).

The above developments go hand in hand with progress in quantitative approaches, including the behavioural turn in public administration studies (Grimmelikhuijsen et al. 2017; Baekgaard and Serritzlew 2016; James and Moseley 2014) and provide the basis for strengthening mixed methods approaches, which have been championed in public administration research (e.g., Hendren et al. 2018).

With these richer methodological and theoretical approaches, accounting, performance management and accountability systems (considered the realm of professional technical expertise), may risk being studied and considered in isolation from the political, institutional, cultural, societal forces which influence them, but are also, importantly, are influenced by them. We therefore advocate that the contemporary domains of public administration research and practice should pay attention to the contextual conditions under which such accounting and performance measurement systems are practised, and at their broader psychological, organizational, societal, political impacts. Under these conditions, interdisciplinarity becomes a pragmatic necessity (Steccolini 2019).

The published studies in this Public Administration symposium suggest that crosscontamination is essential to gain a better, in-depth, understanding of phenomena, and to produce an understanding of their impacts on policies, practices and more general society. 
There are several developments in public administration that can represent useful stimuli for accounting scholars and vice versa, inviting us to explore the role of accounting in modern democracies (and post-democracies) (see, Steccolini 2019). We therefore encourage scholars to explore new aspects, features and roles of accounting so to learn more general lessons on it, and develop more general contributions to accounting and public policy and administration studies by adopting an interdisciplinary stance and by looking not only at the constraints caused by accounting, but also at the possibilities it offers. For example, a future fruitful research avenue may refer to how social media, populism, technological and demographic changes, and the rise of a post-truth society are shaping new possibilities for accounting, performance measurement and accountability systems (e.g., how citizens are involved in accountability processes and governments and political parties and movement are kept accountable by the electorate). A further possible research area which requires attention refers to how accounting and performance management are implicated in networked and hybrid forms of the provisions of public services third, how the multiplicity of roles and uses of accounting and performance management systems in the public sector creates tensions and conflicts, producing constraints and limiting possibilities, but also enabling new solutions and opening new opportunities.

We are confident that the papers in this symposium will provide a basis for strengthening the dialogue between scholars in accounting and public administration and an impetus and encouragement for both communities to explore how accounting, accountability and performance measurement systems considerations are implicated in policy making, public services, and more generally the building and maintenance of states and democracies. 


\section{References}

Ahmad, S., Connolly, C., \& Demirag, I. (2018). A study of the operationalization of management controls in United Kingdom Private Finance Initiative contracts. Public Administration, 1- 17.

Ammons, D.N., \& Rivenbark, W. (2008). Factors influencing the use of performance data to improve municipal services: evidence from the North Carolina benchmarking project. Public Administration Review, 68, 304-331.

Andon, P. (2012). Accounting-related research in PPPs/PFIs: present contributions and future opportunities, Accounting, Auditing \& Accountability Journal, 25, 876 - 924.

Anessi-Pessina, E., Barbera, C., Sicilia, M., \& Steccolini, I. (2016). Public sector budgeting: A European review of accounting and public management journals, Accounting, Auditing \& Accountability Journal, 29, 491-519.

Ansari, S., \& Euske, K. J. (1987). Rational, Rationalizing, and Reifying Uses of Accounting Data in Organizations. Accounting, Organizations and Society, 12, 549-570.

Arnaboldi, M., Lapsley, I., \& Steccolini, I. (2015). Performance management in the public sector: the ultimate challenge. Financial Accountability and Management, 31, 1-22.

Baekgaard M., \& Serritzlew, S. (2016). Interpreting Performance Information. Motivated Reasoning or Unbiased Comprehension. Public Administration Review, 76, 73-82.

Barrows, S., Henderson, M., Peterson, Paul E. \& West, Martin R. (2016). Relative Performance Information and Perceptions of Public Service Quality: Evidence From American School Districts. Journal of Public Administration Research and Theory, 26, 571-83.

Battaglio, R. P., Belardinelli, P., Bellé, N., \& Cantarelli, P. (2018). Behavioral Public Administration ad fontes: A Synthesis of Research on Bounded Rationality, Cognitive Biases, and Nudging in Public Organizations. Public Administration Review, 79, 304-320.

Belardinelli, P., Belle, N., Sicilia, M., \& Steccolini, I. (2018). Framing Effects under Different Uses of Performance Information: An Experimental Study on Public Managers. Public Administration Review, 78, 841-851.

Bellé, N., Belardinelli, P., Cantarelli, P., \& Mele, V. (2019). On iron cages and suboptimal choices: an experimental test of the micro-foundations of isomorphism in the public sector. International Public Management Journal, 22, 1-42.

Bevan, G., \& Hood, C. (2006). What's Measured is What Matters: Targets and Gaming in the English Public Health Care System. Public Administration, 84, 517-538.

Boland, R., \& Pondy, L. R., (1983). Accounting in Organizations: A Union of Natural and Rational Perspectives. Accounting, Organizations and Society, 8, 223-234.

Bracci E., Humphrey, C., Moll, J., \& Steccolini, I. (2015). Public Sector Accounting, Accountability and Austerity: More than Balancing the Books?. Accounting, Auditing and Accountability Journal, 28, 878-908.

Brignall, S., \& Modell, S. (2000). An institutional perspective on performance measurement and management in the 'new public sector'. Management Accounting Research, 11, 281306. 
Broadbent, J., \& Guthrie, J. (1992). Changes in the public sector: a review of recent 'alternative' accounting research. Accounting, Auditing and Accountability Journal, 5, 331.

Broadbent, J., \& Guthrie, J. (2008), Public sector to public services: 20 years of 'contextual' accounting research. Accounting, Auditing and Accountability Journal, 21, 129-169.

Broadbent, J., \& Laughlin. R. (1998). Resisting the 'new public management': absorption and absorbing groups in schools and GP practices in the UK. Accounting, Auditing and Accountability Journal, 11, 403-435.

Broadbent, J., Jacobs, K., \& Laughlin, R. (2001). Organisational resistance strategies to unwanted accounting and finance changes: the case of general medical practice in the UK. Accounting, Auditing and Accountability Journal, 14, 565-586.

Burchell, S., Clubb, C., Hopwood, A., \& Hughes J. (1980). The Role of Accounting in Organizations and Society. Accounting, Organizations and Society, 5, 5-27.

Carter, C., Spence, C., \& McKinlay, A. (2019). Strategic change, leadership and accounting: A triptych of organizational reform. Public Administration, 1- 30.

Coen, D., \& Roberts. A. (2012). A New Age of Uncertainty. Introduction to Special Issue. Governance, 25, 5-9.

De Lancer Julnes, P., \& Holzer, M. (2001). Promoting the utilization of performance measures in public organizations: An empirical study of factors affecting adoption and implementation. Public Administration Review, 61, 693-708.

De Lancer Julnes, P., \& Steccolini, I. (2015). Introduction to Symposium: Performance and Accountability in Complex Settings - Metrics Methods, and Politics. International Review of Public Administration, 20, 329-334.

Van Erp, J., Wallenburg, I., \& Bal, R. (2018) Performance regulation in a networked healthcare system: From cosmetic to institutionalized compliance. Public Administration, 1- 16.

Ferlie, E., Fitzgerald, L., McGivern, G., Dopson, S., \& Bennett, C. (2011). Public Policy Networks and , wicked problems': a nascent solution? Public Administration, 89, 307-324.

Ferry, L., Saliterer, I., Steccolini, I., \& Tucker, B. (Eds.) (2019). An International Analysis of the Research-Practice Gap on Accounting in the Public Services, Palgrave Book, London.

George, B., Baekgaard, M., Decramer, A., Audenaert, M., \& Goeminne, S. (2018). Institutional isomorphism, negativity bias and performance information use by politicians: A survey experiment. Public Administration, 1- 15.

Giacomini, D., Sicilia, M., \& Steccolini, I. (2016). Contextualizing politicians' uses of accounting information: reassurance and ammunition. Public Money \& Management, 36, 483-490.

Goddard, A. (2010). Contemporary public sector accounting research - an international comparison of journal papers. The British Accounting Review, 42, 75-87.

Grimmelikhuijsen, S., Jilke, S., Leth Olsen, A., \& Tummers, L. (2017). Behavioral Public Administration: Combining Insights from Public Administration and Psychology. Public Administration Review, 77, 45-56. 
Guthrie, J., Olson, O., \& Humphrey C. (1999). Debating Developments in New Public Financial Management: The Limits of Global Theorizing and Some New Ways Forward. Financial Accountability and Management, 15, 209-228.

Hatry H. (2007). Performance Measurement: Getting Results. Washington, DC: Urban Institute.

Hendren, K., Luo, Q. E., \& Pandey, S. K. (2018). The State of Mixed Methods Research in Public Administration and Public Policy. Public Administration Review, 78, 904-916.

Hood, C. (1991). A public management for all seasons?. Public Administration, 69, 3-19.

Hood C. (1995). The "new public management" in the 1980s: variations on the theme. Accounting, Organizations Society, 20, 93-109.

Hood, C., \& Peters, G. (2004). The middle aging of new public management: into the age of paradox?. Journal of Public Administration Research and Theory, 14, 267-282.

Hood, C. (2002). The Risk Game and the Blame Game. Government and Opposition, 37, 1537.

Humphrey, C., Miller, P., \& Scapens, R.W. (1993). Accountability and accountable management in the UK public sector, Accounting, Auditing \& Accountability Journal, 6, 7-29.

Humphrey, C., \& Miller, P. (2012). Rethinking impact and redefining responsibility: The parameters and coordinates of accounting and public management reforms. Accounting, Auditing and Accountability Journal, 23, 295-327.

Humphrey, C., Guthrie, J., Jones, L.R., \& Olson, O. (2005). The dynamics of public financial management change in an international context. In Guthrie et. al. (eds): International Public Financial Management Reforms: Progress, Contradictions, Challenges, 1-22

Hvidman, U., \& Andersen, S. C. (2014). Impact of Performance Management in Public and Private Organizations. Journal of Public Administration Research and Theory, 24, 35-58.

Hyndman, N., Liguori, M., Meyer, R.E., Polzer, T., Rota, S., \& Seiwald, J. (2014). The translation and sedimentation of accounting reforms. A comparison of the UK, Austrian and Italian experiences. Critical Perspectives on Accounting, 25, 388-408.

Jacobs, K. (2012). Making sense of social practice: theoretical pluralism in public sector accounting research. Financial Accountability \& Management, 28, 1-25.

Jacobs, K. (2013). Making Sense of Social Practice: Theoretical Pluralism in Public Sector

Accounting Research: A Reply. Financial Accountability and Management, 29, 111-115.

James, O., Jilke, S., \& van Ryzin, G. (2017). Behavioural and experimental public administration: Emerging contributions and new directions. Public Administration, 95, $865-873$.

James O., \& Moseley, A. (2014). Does Performance Information about Public Services Affect Citizens' Perceptions, Satisfaction, and Voice Behaviour? Field Experiments with Absolute and Relative Performance Information. Public Administration, 92, 493-511. 
Johansson, T., \& Siverbo, S. (2009). Explaining the Utilization of Relative Performance Evaluation in Local Government: A Multi-Theoretical Study Using Data from Sweden. Financial Accountability and Management, 25, 197-224.

Korac, S., Saliterer, I., Sicilia, M., \& Steccolini, I. (2019). Contrasting and explaining purposeful and legitimizing uses of performance information: a mayor's perspective. Public Management Review, 1-25.

Kroll, A. (2015). Drivers of Performance Information Use: Systematic Literature Review and Directions for Future Research. Public Performance \& Management Review, 38, 459486.

Kroll, A. (2014). Why performance information use varies among public managers: Testing manager-related explanations. International Public Management Journal, 17, 174-201.

Kurunmäki, (2008). Management Accounting, Economic Reasoning and the New Public Management Reforms. Handbooks of Management Accounting Research, 3, 1371-1383.

Kurunmaki, L., Lapsley, I., \& Melia, K. (2003). Accountingization v. legitimation: a comparative study of the use of accounting information in intensive care, Management Accounting Research, 14, 112-139.

Lapsley, I. (1988). Research in public sector accounting: an appraisal. Accounting, Auditing \& Accountability Journal, 1, 21-33.

Lapsley, I. (1999). Accounting and the new public management: instruments of substantive efficiency or a rationalising modernity?. Financial Accountability and Management, 15, 201-207.

Lapsley, I. (2008). The NPM agenda: back to the future. Financial Accountability and Management, 24, 77-96.

Lapsley, I. (2009). New Public Management: The Cruellest Invention of the Human Spirit?. Abacus, 45, 1-21.

Liguori, M., Steccolini, I. \& Rota, S. (2017). Studying administrative reforms through textual analysis: the case of Italian central government accounting. International Review of Administrative Sciences, 84, 308-333.

Liguori, M., \& Steccolini, I. (2014). Accounting, innovation and public-sector change. Translating reforms into change?. Critical Perspectives on Accounting, 25, 319-323.

Markus, L., \& Pfeffer, J. (1983). Power and the design and implementation of accounting and control systems Accounting. Organizations and Society, 8, 205-218.

Melkers, J., \& Willoughby, K. (2005). Models of performance-measurement use in local governments: Understanding budgeting, communication, and lasting effects. Public Administration Review, 65, 180-191.

Micheli, P., \& Pavlov, A. (2017). What is performance measurement for? Multiple uses of performance information within organizations. Public Administration, 1- 17.

Miller (1994) Accounting as Social and Institutional Practice. 
Miller, P., \& Power, M. (2013). Organizing, and Economizing: Connecting Accounting Research and Organization Theory. The Academy of Management Annals, 7, 37-41.

Miller, P., \& Rose, N. (2008). Governing the Present: Administering Economic, Social and Personal Life, Polity Press, Cambridge.

Miller, P. (2001). Governing by Numbers: Why Calculative Practices Matter. Social Research $68,379-396$.

Miller, P., Kurunmaki, L., \& O’Leary, T. (2008). Accounting, Hybrids and the Management of Risk. Accounting, Organizations and Society, 33, 942-967.

Modell, S. (2013). Making sense of social practice: theoretical pluralism in public sector accounting research: a comment. Financial Accountability and Management, 29, 99-110.

Modell, S. (2009). Institutional research on performance measurement and management in the public sector accounting literature: a review and assessment. Financial Accountability and Management, 25, 277-303.

Moynihan, D. P. (2018). A great schism approaching? Towards a micro and macro public administration. Journal of Behavioral Public Administration, 1, 1-8.

Moynihan, D. P., \& Pandey, S. K. (2010). The Big Question for Performance Management: Why Do Managers Use Performance Information?, Journal of Public Administration Research and Theory, 20, 849-66.

Moynihan, D., Pandey, S., \& Wright, B. (2012a). Prosocial Values and Performance Management Theory: The Link between Perceived Social Impact and Performance Information Use. Governance, 25, 463-483.

Moynihan, D., Pandey, S., \& B. Wright. (2012b). Setting the Table: How Transformational Leadership Fosters Performance Information Use. Journal of Public Administration Research and Theory, 22, 143-164.

Moynihan, D. P. (2009). Through a glass darkly: understanding the effects of performance regimes. Public Performance \& Management Review, 32, 586-598.

Nielsen, P., \& Baekgaard, M. (2013). Performance Information, Blame Avoidance, and Politicians' Attitudes to Spending and Reform: Evidence from an Experiment. Journal of Public Administration Research and Theory, 25, 545-69.

Nielsen, P., \& Moynihan, D.P. (2016). Romanticizing Bureaucratic Leadership? The Politics of How Elected Officials Attribute Responsibility for Performance. Governance, 30, 541559.

Nitzl, Ch., Sicilia, M., \& Steccolini, I. (2018). Exploring the links between different performance information uses, NPM cultural orientation, and organizational performance in the public sector. Public Management Review21, 686-710.

Nowell, B. \& Albrecht, K. (2018). A Reviewer's Guide to Qualitative Rigor. Journal of Public Administration Research and Theory, 29, 348-363.

Olsen, A. L. (2015). Citizen (Dis)satisfaction: An Experimental Equivalence Framing Study. Public Management Review, 75. 469-478. 
Olsen, A. L. (2017). Compared to What? How Social and Historical Reference Points Affect Citizens' Performance Evaluations. Journal of Public Administration Research and Theory, 27, 562-580.

Olson, O., Guthrie, J., \& Humphrey, C. (1998). Global Warning! Debating International Developments in New Public Financial Management, Cappelen Akademisk Forlag, Oslo.

Olson, O., Humphrey, C., \& Guthrie, J. (2001). Caught in an Evaluatory Trap: A Dilemma for Public Services under NPFM. European Accounting Review, 10, 505-522.

Ospina, S., Esteve, M., \& Lee, S. (2018). Assessing Qualitative Studies in Public Administration Research. Public Administration Review, 78, 593-605.

Parker, L. (2012). From privatised to hybrid corporatised higher education: a global financial management discourse. Financial Accountability \& Management, 28, 247-268.

Parker, L.D., \& Northcott, D. (2016). Qualitative generalising in accounting research: concepts and strategies. Accounting, Auditing \& Accountability Journal, 29, 1100-1131.

Power, M. (1997). The Audit Society: Rituals of Verification. Oxford: Oxford University Press.

Power, M. (2000). The Audit Society - Second Thoughts. International Journal of Auditing, 4, 111-19.

Power, M. (2003). Evaluating the Audit Explosion. Law and Policy, 25, 185-202.

Saliterer, I., Korac, S., Moser., B., \& Rondo-Brovetto, P. (2019). How politicians use performance information in a budgetary context: New insights from the central government level. Public Administration, 1-16.

Speklé, R., \& Verbeeten, F. H. M. (2014). The use of performance measurement systems in the public sector: Effects on performance. Management Accounting Research, 25, 131146.

Steccolini, I., (2019). Accounting and the post-new public management: Re-considering publicness in accounting research. Accounting, Auditing \& Accountability Journal, 32, 255-279.

Taylor, J. (2011). Factors influencing the use of performance information for decision making in Australian state agencies. Public Administration, 89, 1316-1334.

Taylor, J. (2009). Strengthening the link between performance measurement and decision making. Public Administration, 87, 853-871.

Ter Bogt, H., \& van Helden, J. (2000). Accounting change in Dutch government: Exploring the gap between expectations and realizations. Management Accounting Research, 11, 263-279.

Triantafillou, P. (2019). Playing a zero-sum game? The pursuit of independence and relevance in performance auditing. Public Administration, 1- 15.

Van Dooren, W., \& Van de Walle, S. (eds.) (2008). Performance Information in the Public Sector. How it is Used. London: Palgrave Macmillan.

Van Helden, J.G., Johnsen, A., \& Vakkuri, J. (2008). Distinctive research patterns on public sector performance measurement of public administration and accounting disciplines. Public Management Review, 10, 641-651. 
Walker, R., Damanpour, F., \& Devece, C. (2011). Management innovation and organizational performance: The mediating effect of performance management. Journal of Public Administration Research and Theory, 21, 367-386.

Wiesel, F., Modell, S., \& Moll, J. (2011). Customer orientation and management control in the public sector: a garbage can analysis. European Accounting Review, 20, 551-581. 